\title{
Pengaruh penambahan Silikon pada remelting piston motor bekas menggunakan tungku induksi terhadap kekuatan tarik dan kekerasan
}

\author{
Eko Nugroho' ${ }^{1 *}$, Eko Budiyanto², Aji Dawam Firdaus ${ }^{3}$ \\ ${ }^{1,2,3}$ Prodi Teknik Mesin, Fakultas Teknik, Universitas Muhammadiyah Metro \\ Jl. Ki Hajar Dewantara 15 A Kota Metro, Lampung, Indonesia \\ *Corresponding author: exonugros@gmail.com
}

\begin{abstract}
Aluminum is one of the most widely used non-ferrous metals in industry and engineering because of its light weight and resistance to corrosion. The purpose of this study is to change the waste of used motor pistons using an induction furnace by recycling or remelting the material and adding a mixture of Silicon with variations of $8 \%, 10 \%$ and 12 $\%$ to improve its mechanical properties. This research was used the main furnace for the smelting. The results of this study in the tensile test showed that the strength and wear strength increased with the addition of silicon elements but became ductile and stiff this happened because the value of the elastic modulus decreased with the addition of Silikon elements, namely at $12 \%$ at $1.06 \mathrm{~N} / \mathrm{mm}^{2}$ and at a variation of $8 \%$ of $1.13 \mathrm{~N} / \mathrm{mm}^{2}$. In the hardness test, it was found that the addition of silicon to aluminum with variations of $8 \%, 10$ $\%$ and $12 \%$ increased the hardness of the material.
\end{abstract}

Keywords: Silicone, remelting, induction furnace, tensile and hardness test.

\begin{abstract}
Abstrak
Alumunium adalah salah satu logam non ferous yang paling banyak digunakan dalam bidang industri maupun keteknikan karna sifatnya yang ringan dan tahan terhadap korosi. Tujuan penelitian ini yaitu untuk mengubah limbah piston motor bekas menggunakan tungku induksi dengan cara mendaur ulang atau remelting bahan tersebut dan menambahkan campuran Silikon dengan variasi $8 \%, 10 \%$ dan $12 \%$ untuk memperbaiki sifat mekasnis nya. Penelitian ini menggunakan tungku induksi untuk peleburannya. Hasil dari penelitian pada uji tarik didapatkan kekuatan tarik dan kekerasan meningkat seiring penambahn unsur Silikon namun menjadi ulet hal ini terjadi karena nilai dari modulus elastisitasnya menurun seiring penambahan unsur Silikon yaitu pada $12 \%$ sebesar $1,06 \mathrm{~N} / \mathrm{mm}^{2}$ dan pada variasi $8 \%$ sebesar $1,13 \mathrm{~N} / \mathrm{mm}^{2}$. Pada uji kekerasan didapatkan bahwa penambahan Silikon pada Aluminium dengan variasi $8 \%, 10 \%$, dan $12 \%$ menambah kekerasan bahan tersebut
\end{abstract}

Kata kunci : Silikon, remelting, tungku induksi, uji tarik dan kekerasan

\section{Pendahuluan}

suatu $\begin{gathered}\text { Pengecoraan logam merupakan } \\ \text { proses }\end{gathered}$ manufaktur yang menggunakan logam, kemudian diolah menjadi logam cair dan cetakan untuk menghasilkan beberapa part dengan bentuk yang mendekati geometri produk jadi. Secara umum proses pengecoran logam meliputi pembuatan cetakan, peleburan logam, penuangan logam cair, pembongkaran cetakan dan pembersihan coran. Biasanya pecairan logam dilakukan dengan menggunakan tungku induksi atautanur induksi. Pengecoran logam memiliki keunggulan yang dapat menghasilkan produk dengan bentuk yang sederhana sampai bentuk yang rumit dengan berat bervariasi, mulai dari satuan gram sampai satuan ton serta proses 
finishing-nya yang minimum sehingga dapat mengurangi biaya dan waktu proses.

Pengecoraan logam merupakan

suatu proses manufaktur yang menggunakan logam, kemudian diolah menjadi logam cair dan cetakan untuk menghasilkan beberapa part dengan bentuk yang mendekati geometri produk jadi. Secara umum proses pengecoran logam meliputi pembuatan cetakan, peleburan logam, penuangan logam cair, pembongkaran cetakan dan pembersihan coran. Biasanya pecairan logam dilakukan dengan menggunakan tungku induksi atautanur induksi. Pengecoran logam memiliki keunggulan yang dapat menghasilkan produk dengan bentuk yang sederhana sampai bentuk yang rumit dengan berat bervariasi, mulai dari satuan gram sampai satuan ton serta proses finishing-nya yang minimum sehingga dapat mengurangi biaya dan waktu proses. Proses ini banyak digunakan terutama dalam bidang industry.

\section{Tinjauan Pustaka}

\section{Tungku Induksi}

Tungku induksi adalah tungku listrik yang memanfaatkan prinsip induksi untuk memanaskan logam hingga titik leburnya dimana panas yang diterapkan oleh pemanasan induksi medium konduktif (biasanya logam) frekuensi operasi berkisar dari frekuensi yang digunakan antara $60 \mathrm{~Hz}$ sampai dengan $400 \mathrm{kHz}$ bahkan bisa lebih tinggi hal tersebut tergantung dari material yang mencair, kapasitas tungku dan kecepatan pencairan yang diperlukan. Frekuensi medan magnet yang tinggi juga dapat berfungsi untuk mengaduk agar menghomogenkan komposisi logam cair. Tungku induksi banyak digunakan dalam peleburan modern karena sebagai metode peleburan logam yang bersih dari pada peleburan dari tungku reverberatory atau kupola. Ukuran tungku berkisar dari satu kilogram kapasitas sampai seratus ton kapasitas dan digunakan untuk meleburkan berbagai jenis logam Seperti Besi, Baja, Alumunium Dan Tembaga.

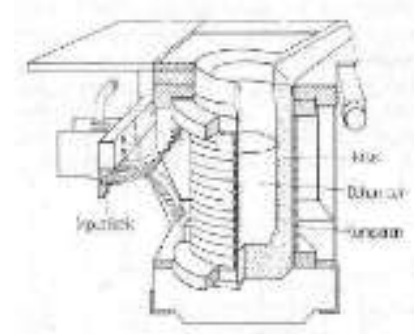

Gambar 1. Tungku induksi

\section{Uji Tarik}

Uji tarik adalah suatu metode yang digunakan untuk menguji kekuatan suatu bahan/material dengan cara memberikan beban gaya yang sesumbu. Hasil yang didapatkan dari pengujian tarik sangat penting untuk rekayasa teknik dan desain produk karena mengahsilkan data kekuatan material. Pengujian uji tarik digunakan untuk mengukur ketahanan suatu material terhadap gaya statis yang diberikan secara lambat. Salah satu cara untuk mengetahui besaran sifat mekanik dari logam adalah dengan uji tarik. Sifat mekanik yang dapat diketahui adalah kekuatan dan elastisitas dari logam tersebut

Pengujian ini sangat sederhana, tidak mahal dan sudah mengalami standarisasi di seluruh dunia, misalnya di Amerika dengan ASTM E8 dan Jepang dengan JIS 2241. Dengan menarik suatu bahan kita akan segera mengetahui bagaimana bahan tersebut bereaksi terhadap tenaga tarikan dan mengetahui sejauh mana material itu bertambah panjang. Alat eksperimen untuk uji tarik ini harus memiliki cengkeraman (grip) yang kuat dan kekakuan yang tinggi (highly stiff).

Pengujian tarik ini dilakukan untuk mengetahui sifat-sifat mekanis suatu material, khususnya logam diantara sifatsifat mekanis yang dapat diketahui dari hasil pengujian tarik adalah sebagai berikut:

a) Kekuatan tarik.

b) Kuat luluh dari material.

c) Keuletan dari material.

d) Modulus elastisitas dari material.

e) Kelentingan dari suatu material.

f) Ketangguhan. 


\section{Prinsip Kerja Uji Tarik}

Mesin uji tarik untuk material yang terdiri atas beberapa bagian, Bagian atas disebut sebagai Crosshead, ataubagian yang bergerakyang menarik benda uji, Sepasang ulir cylinder akan membawa atau menggerakan bagian crosshead. Sementara itu di bagian bawah dibuat static. Dibagian crosshead terdapat sensor loadcell yang akan mengukur besarnya gaya tarik, sedangkan untuk mengukur perubahan panjang digunakan strain gages atau extensometer.

Dengan menarik suatu bahan kita akan mengetahui bagaimana bahan tersebut bereaksi terhadap tenaga tarikan dan mengetahui sejauh mana material itu bertambah panjang.

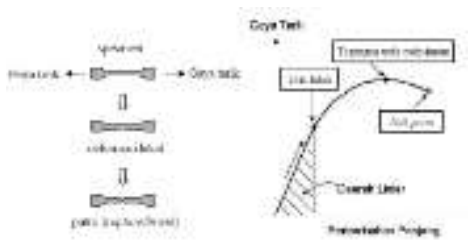

Gambar 2. Gambaran singkat uji tarik

\section{Uji Kekerasan}

Kekerasan suatu material menyatakan kemampuan material tersebut untuk menahan deformasi plastis. Kekerasan didefinisikan sebagai ketahanan bahan terhadap penetrasi pada permukaannya. Dapat diperkirakan bahwa terdapat hubungan antara kekerasan dan kekuatan bahan.

Uji Kekerasan adalah bentuk uji material yang sering digunakan untuk menentukan mutu material. Pengujian ini relatif mudah dilakukan dan sepenuhnya tidak merusak selain itu instrument yang digunakan harganya relatif lebih murah dibandingkan jenis pengujian lainnya. Berikut adalah macam macam metode pengujian kerkerasanberdasarkan nilai kekerasan dan bahan benda uji.

\section{Uji Kekerasan Rockwell}

Prinsip dasar uji kekerasan Rockwell dengan mengukur kedalaman material dengan cara memberikan beban indentansi menggunakan beban minor kemudian dilanjutkan dengan memberikan beban major. Awalnya beban minor diterapkan dengan posisi nol datum yang sudah ditetapkan. Beban utama (major) kemudian diterapkan beberapa waktu kemudian diangkat kembali dengan posisi beban minor masih tertahan atau diterapkan. Angka yang dihasilkan dari uji kekerasan rockwell mewakili perbedaan kedalaman dari posisi nol datum yang merupakan akibat dari penerapan beban major. Uji kekerasan rockwell dapat memberikan hasil pengukuran dengan cepat tanpa harus membutuhkan persyaratan berupa pengukuran dimensi sekunder. Jenis indentor yang paling sering digunakan yaitu berbentuk diamond cone (kerucut) dengan sudut 120 derajat untuk menguji kekerasan material logam.

\section{Metode Penelitian}

Penelitian dilakasanakan di Laboratorium Teknik Mesin Universitas Muhamadiyah Metro. Dalam penelitian ini metode yang digunakan adalah pengecoran logam. pengecoran logam yaitu suatu proses manufaktur yang menggunakan logam, kemudian diolah menjadi logam cair pada temperatur tertentu dan dituangkan atau ditekan kedalam cetakan yang memiliki rongga cetak (cavity)dan dibiarkan mendingin dan membeku untuk menghasilkan beberapa part dengan bentuk yang mendekati geometri produk jadi.

Bahan dan alat yang digunakan:

1) Alumunium paduan (Al-Si)

2) Silicon

3) Tungku induksi

4) Timbangan

5) Cetakan pasir

6) Thermogun

7) Mesin gerinda

8) Kertas amplas

9) Jangka sorong

10) Alat uji tarik

11) Alat uji kekerasan

Ada beberapa langkah dalam melakukan peleburan aluminium, yaitu ; 1) Persiapan Cetakan 
Dalam penelitian ini menggunakan cetakan logam

2) Persiapan Burner Furnace

a) Bahan dimasukkan kedalam furnace dan menyetel temperatur suhu hingga mencapai $770^{\circ} \mathrm{C}$

b) Setelah benda kerja dicairkan kemudian furnace dibuka dan dilakukan pengadukan selama beberapa saat.

3) Penuangan cairan logam

Setelah benda kerja mencair, lalu dituangkan ke dalam cetakan logam

4) Proses pendinginan

Cairan logam dibiarkan hingga membeku dalam temperatur kamar.

5) Proses finishing, proses ini terbagi menjadi :

a) Pemeriksa pada produk coran

b) Pembersihkan pada produk coran

c) Pemotongan bagian yang tidak sesuai cetakan

\section{Hasil Dan Pembahasan}

Berdasarkan hasil pengujian tarik yang dilakukan pada laboratorium Balai Penelitian Teknologi Mineral LIPI Lampung, didapatkan sebagai berikut:

Tabel 1. Data hasil uji tarik

\begin{tabular}{|c|c|c|c|c|c|}
\hline \multicolumn{6}{|c|}{ Hasil uji tarik } \\
\hline 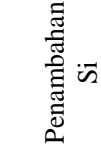 & 蔦 & 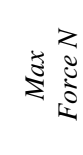 & 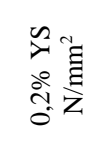 & $\approx \frac{\mathcal{E}}{\mathrm{z}}$ & 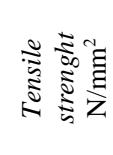 \\
\hline $0 \%$ & \multirow{4}{*}{28,26} & 130 & 3,284 & 4,30 & 4,60 \\
\hline $8 \%$ & & 186 & 5,687 & 6,16 & 6,58 \\
\hline $10 \%$ & & 215 & 6,492 & 7,11 & 7,60 \\
\hline $12 \%$ & & 347 & 7,157 & 11,48 & 12,27 \\
\hline
\end{tabular}

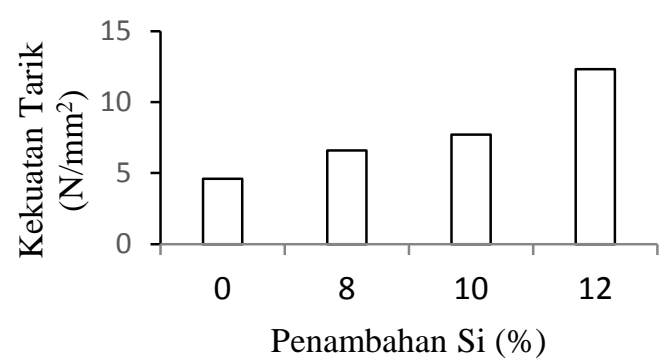

Gambar 2. Grafik kekuatan tarik masing-masing spesimen
Dari penjelasan gambar 2 diketahui nilai tertinggi dari kekuatan tarik yaitu pada spesimen dengan penambahan $\mathrm{Si} 12 \%$ dengan nilai tegangan $12,27 \mathrm{~N} / \mathrm{mm}^{2}$ dan pada spesimen dengan penambahan $\mathrm{Si} 10$ $\%$ nilai kekuatan tariknya yaitu 7,60 $\mathrm{N} / \mathrm{mm}^{2}$, sedangkan untuk nilai kekuatan tarik terendah terdapat pada spesimen dengan penambahan $\mathrm{Si} 8 \%$ dengan nilai $6,58 \mathrm{~N} / \mathrm{mm}^{2}$.

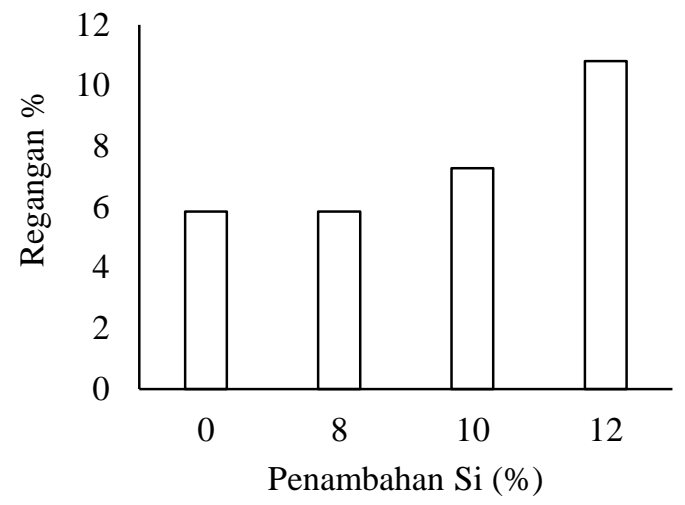

Gambar 3. Grafik perbandingan regangan

Dari penjelasan grafik diatas diketahui nilai tertinggi dari nilai regangan yaitu pada spesimen dengan penambahan Si $12 \%$ dengan nilai $11,48 \%$ dan pada spesimen $10 \%$ nilai regangan yaitu $6,70 \%$ sedangkan untuk nilai regangan terendah terdapat pada spesimen dengan penambahan Si 8\% dengan nilai 5,81\%.

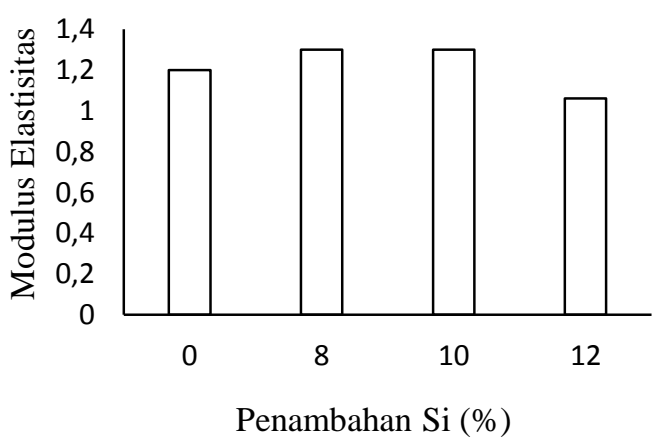

Gambar 4. Grafik perbandingan Modulus Elastisitas

Dari penjelasan Gambar 4, diketahui nilai tertinggi dari nilai modulus elastisitas yaitu pada spesimen dengan penambahan Si $8 \%$ dan $10 \%$ dengan nilai $1,13 \mathrm{~N} / \mathrm{mm}^{2}$ sedangkan untuk nilai regangan terendah terdapat pada spesimen 
dengan penambahan $\mathrm{Si} 12 \%$ dengan nilai $1,06 \mathrm{~N} / \mathrm{mm}^{2}$.

Tabel 2. Data hasil uji kekerasan

\begin{tabular}{ccccccc}
\hline $\begin{array}{c}\text { Penamb } \\
\text { ahan Si }\end{array}$ & \multicolumn{4}{c}{ Hasil Pengujian (HRB) } & $\begin{array}{c}\text { Rata- } \\
\text { rata } \\
\text { (HRB) }\end{array}$ \\
\hline $0 \%$ & 67,3 & 67,9 & 68,1 & 68,4 & 67,9 & 67,9 \\
\hline $8 \%$ & 104, & 73,7 & 84,5 & 70,5 & 77,0 & 80,6 \\
\hline $10 \%$ & 107,8 & 98,7 & 92,2 & 75,7 & 91,2 & 93,1 \\
\hline $12 \%$ & 100,5 & 98,2 & 97,1 & 91,1 & 99,7 & 97,3 \\
\hline
\end{tabular}

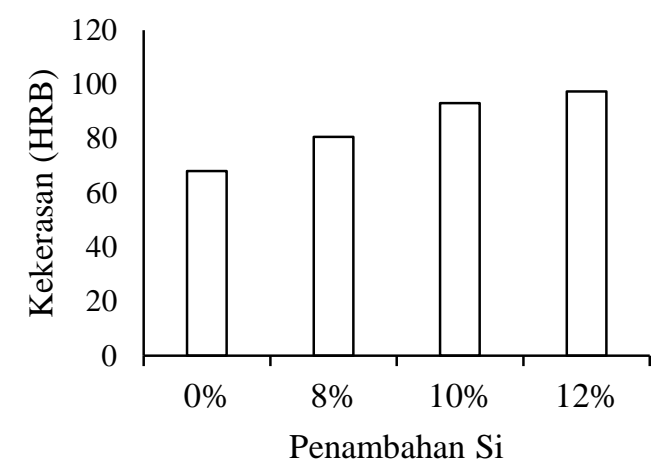

Gambar 5. Grafik nilai kekerasan rata-rata setiap spesimen

Dari Gambar 5 diketahui bahwa nilai rata-rata tertinggi yaitu pada spesimen dengan penambahan Si $12 \%$ dengan nilai 97 HRB dan pada spesimen $10 \%$ nilai 93 sedangkan untuk nilai kekerasan terendah terdapat pada spesimen dengan penambahan Si 8\% dengan nilai $80 \mathrm{HRB}$.

\section{Kesimpulan}

Nilai tertinggi dari kekuatan tarik yaitu pada spesimen dengan penambahan Si $12 \%$ dengan nilai tegangan $12,27 \mathrm{~N} / \mathrm{mm}^{2}$ dan pada spesimen dengan penambahan $\mathrm{Si}$ $10 \%$ nilai kekuatan tariknya yaitu 7,60 $\mathrm{N} / \mathrm{mm}^{2}$ sedangkan untuk nilai kekuatan tarik terendah terdapat pada spesimen dengan penambahan Si $8 \%$ dengan nilai $6,58 \mathrm{~N} / \mathrm{mm}^{2}$. Dari hasil tersebut disimpulkan bahwa semakin tinggi kadar silikon yang ditambahkan dalam alumunium pada kadar tertentu maka semakin tinggi juga nilai kekuatan tarik tersebut yang artinya kekuatan tariknya meningkat.

Dari hasil pengujian kekerasan pada spesimen dengan penambahan Si 8\%, 10\%, dan $12 \%$ didapatkan nilai kekerasan tertinggi yaitu pada spesimen dengan penambahan $\mathrm{Si} 12 \%$ dengan nilai rata-rata 97 HRB, dan nilai kekerasan terendah dengan nilai rata-rata 87 pada spesimen dengan penambahan Si 8\%. Maka dapat diartikan semakin tinggi campuran silikon pada kadar tertentu maka semakin tinggi juga nilai kekerasan tersebut pada kadar tertentu.

\section{Referensi}

[1]. Aljufri, 2014, Analisa Pengujian Tarik Statik Hasil Pengelasan Tig Pada Material Al-Mg 5083 Menggunakan Analisis Statistik Metodeanova (Varian). Jurusan Teknik Mesin (Manufaktur). Universitas Malikussaleh Aceh Utara.

[2]. Budiyanto, 2018, Uji Ketahanan Fatik Aluminium Scrap Hasil Remelting Piston Bekas Menggunakan Alat Uji Fatik Tipe Rotary Bending, Jurusan Teknik Mesin, Universitas Muhammadiyah Metro. Vol 7 (1).

[3]. Nurhadi, 2010, Studi Karakteristik Material Piston Dan Pengembangan Prototipe Piston Berbasis Limbah Piston Bekas Teknik Mesin. Universitas Diponegoro Semarang.

[4]. Purnawan, 2016, Analisa Kekuatan Tarik Dan Komposisi Bahan Paduan Aluminium Limbah Piston Dengan Metode Metal Casting Untuk Bahan Jendela Kapal, Fakultas Teknik. Universitas Diponegoro.

[5]. Ponco, 2016, Pengaruh Unsur Silikon Pada Aluminium Alloy (Al - Si) Terhadap Sifat Mekanis Dan Struktur Mikro, Jurusan Teknik Mesin. Fakultas Teknik Universitas Tarumanagara.

[6]. Purwanto, 2010, Pengaruh Pengecoran Ulang Terhadap Kekuatan Tarik Dan Kekerasan Pada Aluminium Cor Dengan Cetakan Pasir, Teknik Mesin. 
Universitas Wahid Hasyim

Semarang.

[7]. Septiadi, 2016, Analisa Pengaruh Variasi Media Quenching Dan Penambahan Silikon Pada Paduan Al-Si Remelting Velg Sepeda Motor Terhadap Sifat Fisik Dan Mekanis. Fakultasteknik. Universitas Sebelas Maret.

[8]. Syahbardia, 2018, Pembuatan Tungku Induksi Sederhana. Teknik Mesin.Universitas Diponegoro. Vol 3.

[9]. Wibowo, 2012, Pengaruh Variasi Jenis Cetakan Dan Penambahan Serbuk Dry Cell Bekas Terhadap Porositas Hasil Remelting Al - 9\% Si Berbasis Piston Bekas. Fakultas Keguruan Dan Pendidikan. Universitas Sebelas Maret.

[10]. Nugroho E, Handono SD, Asroni A, Wahidin W. Pengaruh Temperatur dan Media Pendingin pada Proses Heat Treatment Baja AISI 1045 terhadap Kekerasan dan Laju Korosi. Turbo: Jurnal Program Studi Teknik Mesin. 2019 Jul $9 ; 8(1)$. 